\title{
SOME OBSERVATIONS OF BIRDS AT CREE LAKE, SASKATCHEWAN
}

by D. Wayne Davis, University of Arkansas, Fayetteville, Arkansas

A study of birds at Cree Lake, Saskatchewan in the summer of 1963 was briefly reported by $F$. W. Lahrman (1964). The present paper is a summary of some incidental observations made during the course of a study of the Red Squirrel at Cree Lake in the summers of 1960, 1964, and 1965 , a project supported by the U.S. National Science Foundation and the Wildlife Branch of the Saskatchewan Department of Natural Resources. Most of my bird records were made during 1965, when I was in the area from April 15 to August 17, and unless otherwise shown, dates are for that year. In mid-April, there were a few spots free from snow on the sandy southern slopes. However, late snow storms from April 15 to April 22 added a covering of new snow which probably slowed the influx of migrating birds. Although I saw some of the species listed by Lahrman, I have not included these except when I have early arrival dates or other additional information to record. Species not reported by Lahrman are marked with an asterisk. Thanks are due H. S. Dommasch, C. L. Ferguson, C. S. Houston, R. W. Nero and others for assistance and information.

\section{SPECIES ACCOUNT}

Common Loon: First arrival, May 9.

(RED-THROATED LOON): Hypothetical. Several times I heard a bird call (which reminded me of coyotes or a scream) at the southwest side of Lazy Edward Bay. I described this call to Fred Lahrman and he said it could have been the call of a Red-throated Loon. I did not see any of these loons, however.

* Red-NECked Grebe: Recorded.

CANAdA Goose: Canada Geese began to arrive in small flocks about April 30 and reached peak numbers May 3. Many were seen in the narrows between Rushmer Peninsula and Mid-

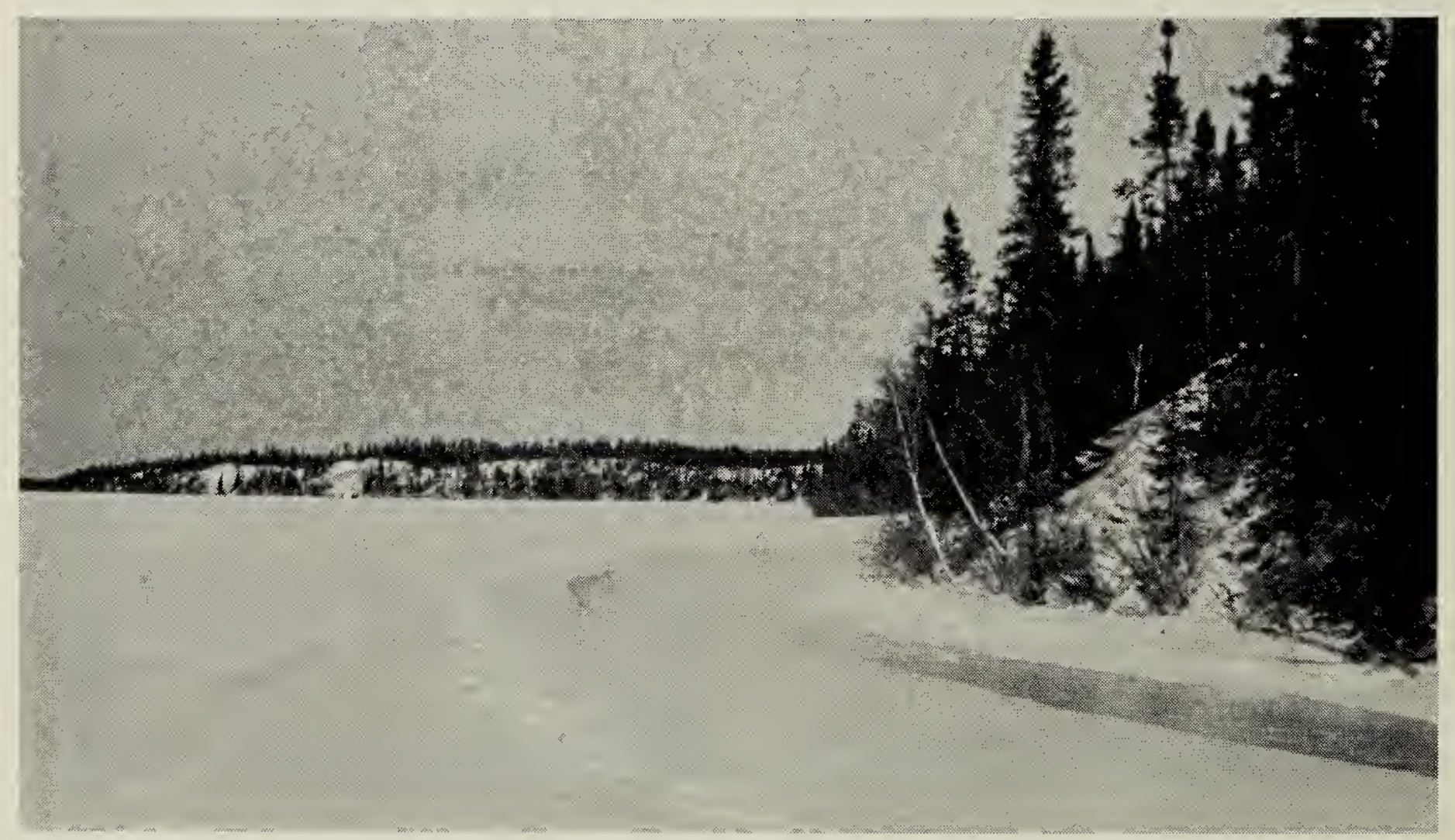

Rushmer Peninsula, Cree Lake, April 20, 1965

Photo by Wayne Davis 
dleton Island. Probably a dozen were killed by trappers. Martin Engeman reported that geese nest in the smaller lakes east of Cree Lake. A female and young were seen in July at the southeast end of Lazy Edward Bay by Charles McCullough. A flock of 50 to 60 flew over Rushmer Peninsula at 8:00 p.m. on June 9. The birds were headed north in the direction of the Cree River. These were possibly wandering non-breeders (see Sterling, 1963).

MALLARD: A few pairs were seen on May 3. On July 2, a female Mallard with young was observed on a small pond between Widdess (Jackfish) Bay and Seaby Lake.

PinTAIL: A lone drake was seen on May 3.

COMmon Merganser: First arrival, May 14.

BALd EAgLe: April 28: Lawrence John spotted an eagle standing near the shore of an island about five miles southeast of Rushmer Peninsula.

June 11: A mature eagle was seen about one mile downstream from the head of the Cree River. This bird may have been nesting at the site described by Lahrman (1964).

June 22: A mature eagle was seen near the north end of Rushmer Peninsula. Several other sightings of eagles in this area took place, the last observation being on June 28. It was assumed that the sightings were of the first bird or its mate. No nest was found.

June 22: An immature was noted just before dusk about two miles from the southern tip of Rushmer Peninsula.

June 24: A nest with two young was found by $H$. S. Dommasch and myself on Morrison Island. Dr. Stuart Houston banded these young on July 17. The large nest was approximately 30 feet high in a jack pine. Skeletons of Northern Pike, Esox lucius Linnaeus, and suckers (Catostomidae) were found at the base of the tree.

June 24: Two men staying at Cree Lake for the summer chopped down
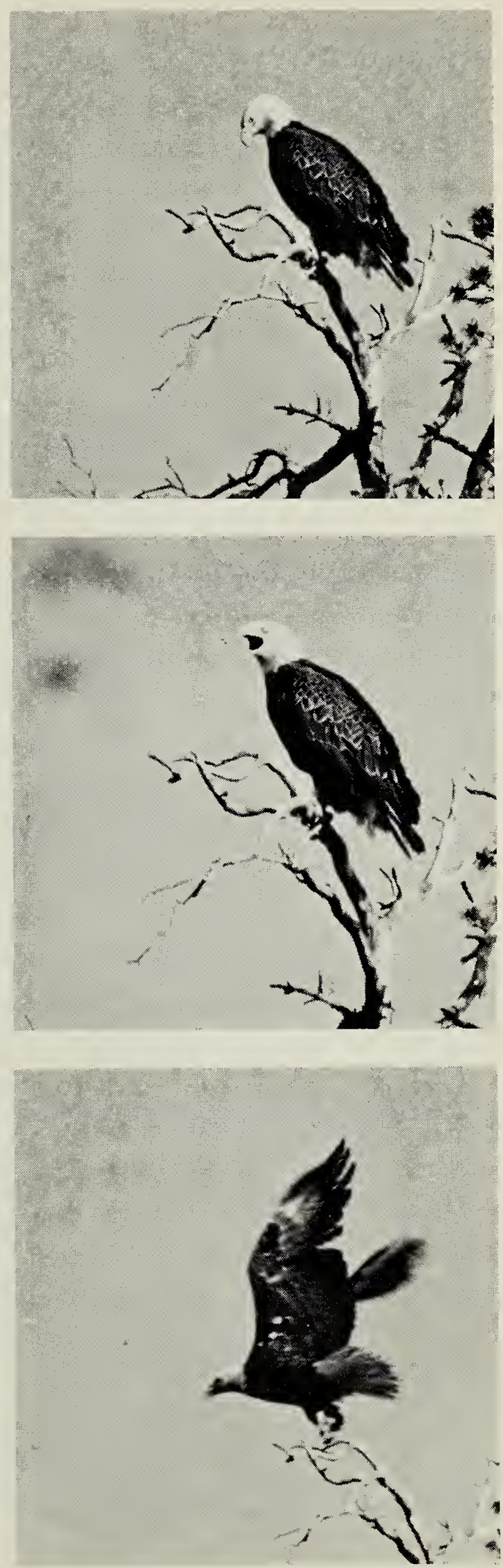

Photos by Hans Dommasch

Bald Eagle, Cree Lake, June, 1965 


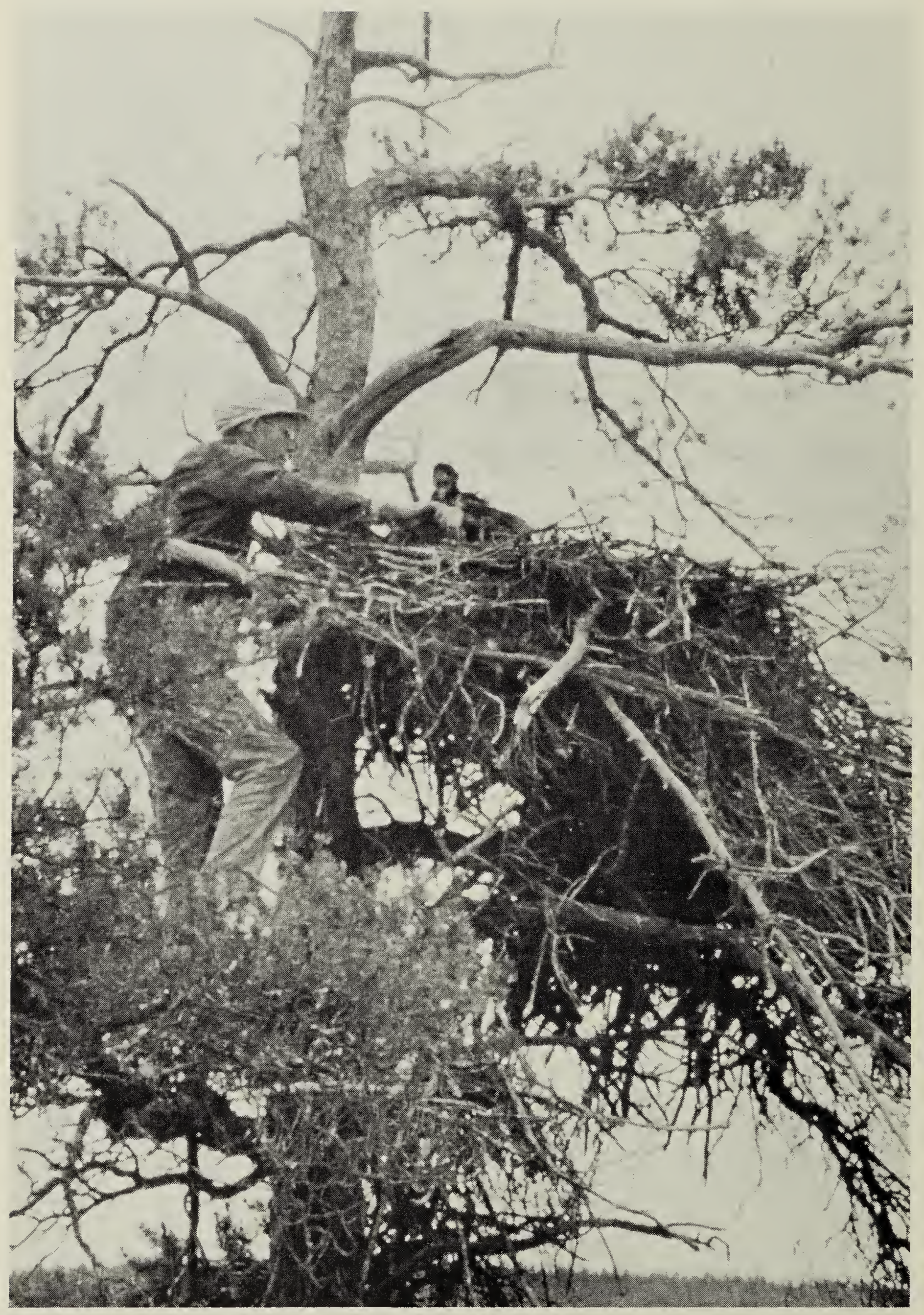

Dr. Stuart Houston at Bald Eagle nest, Cree Lake, July 17, 1965 
a jack pine which held a Bald Eagle nest (on the southwest shore of Cree Lake) and removed the two young from the nest. The young Bald Eagles were raised by hand. One, which was banded by Dr. Houston on July 17, was found dead during the latter part of November, 1965, near Swan Lake in extreme southern Manitaba.

July 8: An immature Bald Eagle was sighted at the east entrance to Lazy Edward Bay.

July 23: The natives told me of a nest which had been used for several years in lower Lansdowne Lake. I portaged into this area in hopes of banding the young. The nest was not found at the expected spot and it was assumed that the tree had fallen or that the nest had blown down. A mature Bald Eagle was circling in the area and the nest may have been nearby.

July 25: Two nests without young were found at the southeast side of Lazy Edward Bay near a small stream. The nests, located 30 feet up in jack pines, were not present in 1964. A mature eagle was perched in a nearby tree.

July 26: An adult was spotted sitting in a black spruce tree at the northwest end of Lazy Edward Bay.

Charlie McCullough and Prosper Bachattala told me that a pair nested on the west shore of Grey Island during the summer of 1964. McCullough and the late Henry Weitzel (pers. corres.) saw an albino eagle at Cree Lake a few years ago. This eagle was apparently on the lake sometime between 1956 and 1960 .

At one time the Bald Eagle at Cree Lake was unmercifully slaughtered. Nesting trees were chopped down and the eggs and nestlings were used for food or destroyed. Adult birds were shot whenever possible. Mrs. J. K. Johnson of Big River, Sask., and some of the trappers and fishermen, feel that the Bald Eagle at Cree Lake has declined in number from what they were 15 or 20 years ago. In recent years the Bald Eagle has not been harassed so much. This is because some of the older trappers have

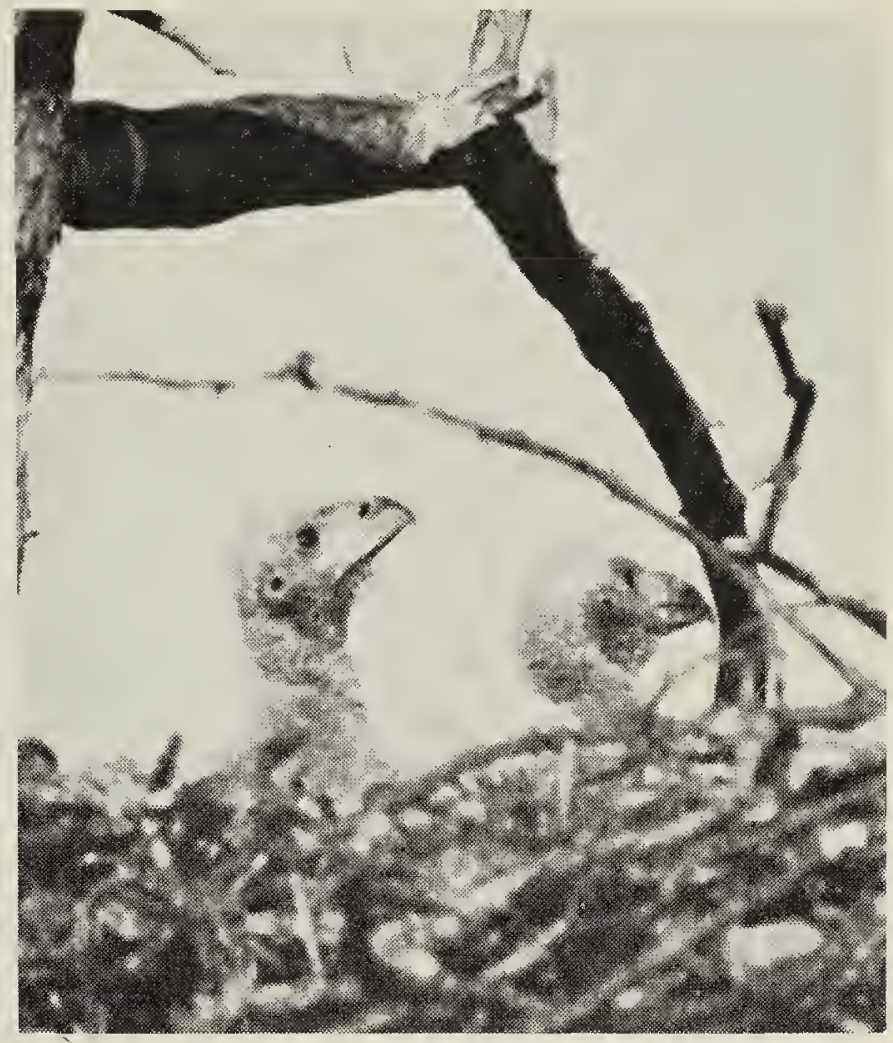

Photo by Hans Dommasch

Bald Eagle young in nest,

Cree Lake, June, 1965

died or moved away; many of the trappers have come to realize that the Bald Eagle does little harm; also Conservation Officers have had an influence in preventing the destruction of this bird.

* Marsh Hawk: One on May 10; no other records.

OSPREY: During the summer of 1964 three Osprey nests were found. One pair nested on a small island two and one-half miles east of Turner Island. The nest was approximately 40 feet high in the top of a jack pine. I did not visit this island in 1965 . The other two nests were located in Lazy Edward Bay. One nest was located in the top of a jack pine west of the bay entrance. The young were seen flying near the nest about the middle of August. This nest was also used again in 1965. On July 17, Dr. Houston banded four young in this nest. One of the young was shot at the National Fish Hatchery, Santa Rosa, New Mexico, on September 20, 1965. It had thus travelled about 1,650 miles nearly due south in approximately one month. The third nest found in 1964 was located two and one-half miles southwest of the bay entrance on a narrow peninsula. 
The nest was 35 feet from the ground in the top of a black spruce. It was abandoned in 1965, but Osprey were seen nearby several times and may have built a new nest.

Sparrow Hawk: First arrival, May 4. On July 17 three young in a nest in the wall of a building were banded by Dr. Houston. The young were almost ready to leave the nest. Sparrow Hawks had also nested in the building in 1964. In late June of 1960 I found a half-grown Sparrow Hawk in a hollow jack pine snag.

Spruce Grouse: On June 5 one was flushed from a nest. Many eggs were in the nest, but since a dog was with me I was unable to make an accurate count.

* Willow Ptarmigan: One was caught on April 15 in a large-mesh fish net set by one of the natives. Few ptarmigan had been at Cree Lake during the winter of 1964-65.

\section{* (SharP - TAIled Grouse): Hypo-} thetical. Charlie McCullough, radio operator at Cree Lake, told me that "prairie chickens" sometimes come to Cree Lake during the winter. The local people evidently shoot and eat them.

Greater Yellowlegs: Many were seen in the area which the local residents call Muskeg Bay. It is located at the west side of Lazy Edward Bay. The Yellowlegs were quite upset by my presence and acted as if they were nesting. Muskeg Bay probably covers 200 acres and is interlaced with narrow waterways. Much of the muskeg is covered with grasses but there are also pitcher plants, shrubs, occasional black spruce or tamarack, and a number of herbs. In one day at this bog I saw moose, beaver, muskrat, teal, Mallards, Greater Yellowlegs, Common Loon, Common Tern, Herring Gull, Sparrow Hawk, various sparrows, Red-winged Blackbirds, and many other species. I feel it is the most interesting area for birds at Cree Lake and certainly shouldn't be missed in future studies at Cree.
Herring GULL: Some arrived on May 1, when there were only small pools of open water. On July 2 a young one was seen and photographed and many nests with eggs were found on a nearby island.

COMmon TERN: H. S. Dommasch of Saskatoon and I found a nest with eggs on a small rocky island on June 21.

* SNowy OwL: The carcass of a Snowy Owl was recovered from a fish net in the spring of 1965 .

* Hawk Owl: On June 24, 1964, a pair and one young were found on an island five miles northeast of Turner Island. The young owl had already left the nest. One was seen on August 7,8 , and 9 on a black spruce-covered island one mile east of Turner Island. The owl was first noted on August 7 sitting on a snag a few feet from a squirrel in a trap. The owl was harassing two other squirrels on August 8. On that afternoon my pet squirrel, Snoopy II (which I allowed to run free about camp) was severely clawed about the rump and hind legs. I assumed the Hawk Owl did this for the owl was seen near camp that afternoon. The next day (August 9) I heard a Red Squirrel chattering and saw the Hawk Owl sitting a few feet away. The owl was collected and donated to the zoology collection, University of Saskatchewan, Regina Campus.

Gray JAY: The first young darkcolored Gray Jays were noted on May 27 in the jack pine forest on Middleton Island. They apparently had been out of the nest for several days. During the next few days several were caught in live-traps. Often whole family groups were seen together. The natives told me that while on their traplines at 20-30 degrees below zero, they had found Gray Jays sitting on eggs.

Common Raven: Ravens stay at Cree Lake during the winter and nest in early spring. Two young Ravens, recently out of the nest, were found 
on a jack pine-covered island northwest of the D.N.R. patrol cabin on June 18,1964 . A pair again nested on this island in 1965 . Ravens apparently have some difficulty in finding food at Cree Lake during the winter. Martin Engeman told me that the Ravens would follow him out to his fish nets and wait for handouts. On May 3 I counted two Ravens and six Herring Gulls feeding on suckers that Martin had thrown to them. They often steal food from the dogs during the winter.

Common CRow: Crows were present at Cree Lake on approximately April 10, according to Martin Engeman. Snowstorms which lasted until April 22 apparently drove them from the area. They were frequently seen the last week in April.

RobIN : First arrival, May 6.

* Swainson's Thrush: Two live birds were caught in squirrel livetraps in July on an island in Lazy Edward Bay. In 1960, I collected a specimen and gave it to the Biology Museum at the University of Saskatchewan, Saskatoon. Swainson's Thrushes are not abundant at Cree Lake.

Bohemian WAXwing: Two were seen on April 18.

* Starling: On April 29 at 11:00 a.m. a Starling was seen feeding on the ground near a trapper's cabin. The bird was studied through binoculars and identification was certain. At 3:00 p.m. two Starlings came near the same cabin. These birds were also observed at that time by trappers Martin Engeman, Lawrence John, and Alfred Montgrant who had never before seen a Starling at Cree Lake. No Starlings were seen again during the spring or summer. This is the first record for this species in Saskatchewan north of the Churchill River system (Nero, 1963; and pers. corres., Nero, 1965). Note that they have occurred far to the north of this region (Kuyt, 1965).

* RED - Winged BlackBiRd: These were common in the marshy areas (Muskeg Bay) at the west end of
Lazy Edward Bay. Red-winged Blackbirds were seen often during the summer in this area and probably nest.

* Rose - breasted Grosbeak: Three males were seen near Martin Engeman's cabin on Rushmer Peninsula on May 25. These or other males were seen again the following day but were not recorded after that. They are evidently not summer residents at Cree Lake. This is the first record for this species in Saskatchewan north of the Churchill River System (Nero, 1963; and pers. corres., Nero, 1965).

* Pine Grosbeak: A male and a female were seen in late afternoon on August 12, on a black spruce-covered island one mile southeast of Turner Island. These are the only Pine Grosbeaks I have ever seen at Cree Lake.

Pine Siskin: A flock was seen on May 6.

Slate-Colored Junco: Many came to a feeding box on May 10. One was observed on a nest located at the edge of a fallen tree top on June 3.

* Harris' Sparrow : Many came to a feeding box on May 10. Harris' Sparrows were seen at Rushmer Peninsula until about May 17, and were not recorded after that. They are not summer residents.

White-Crowned Sparrow: Many came to a feeding box on May 10.

* Snow Bunting: A large flock was observed scratching in the snow on April 18.

\section{LITERATURE CITED}

Kuyt, E. 1965. A breeding record of the Starling at Lookout Point, Northwest Territories. Blue Jay, $23: 83-84$.

Lahrman, F. W. 1964. The bird life at Cree Lake, summer 1963. Blue Jay, $22: 7-8$.

Nero, R. W. 1963. Birds of the Lake Athabasca region, Saskatchewan. Spec. Pub. No. 5, Sask. Nat. Hist. Soc., Regina, 143 pp. \& 12 plates.

Sterling, E. T. 1963. Wascana goose summers on the Arctic prairie. Blue Jay, 21:134-135. 